удк 343.973

DOI https://doi.org/10.32837/apdp.v0i85.1822

О. М. Бурда

\title{
СОЦІАЛЬНО-ДЕМОГРАФІЧНА ХАРАКТЕРИСТИКА МАГАЗИННОГО КРАДІЯ
}

Постановка проблеми. Явище крадіжок із закладів роздрібної торгівлі зазвичай сприймається та оцінюється суспільством з огляду на збиральний образ особливостей кримінальної поведінки певної частини населення - магазинних крадіїв. Тому першочерговим завданням дослідника повинно бути прагнення дати відповідь на такі запитання: хто ці особи за статтю, віком, сімейним становищем, рівнем освіти, трудовою зайнятістю, які особливості злочинної поведінки їм притаманні?

Аналіз останніх досліджень і публікацій. Питанням, присвяченим особі злочинця, присвячено роботи вітчизняних науковців Б.М Головкіна, I.М. Даньшина, А.П. Закалюка, О.М Джужи та інших. Однак особа магазинного крадія як спеціальний предмет дослідження не розглядалася.

Формулювання мети. У статті здійснено спробу охарактеризувати соціально-демографічні ознаки магазинного крадія.

Виклад основного матеріалу. В кримінологічній літературі існують різні підходи до визначення поняття «особа злочинця». Одні науковці вважають, що особа злочинця якісно відрізняється від законослухняних громадян, а інші вказують, що така особа просто набуває певних негативних властивостей у момент вчинення злочину.

На думку I.М. Даньшина, особа злочинця - це сукупність суттєвих і стійких соціальних властивостей та рис, соціально значущих біопсихологічних особливостей індивіда, які, об’єктивно реалізуючись у конкретному злочині, надають вчиненому діянню характер суспільної небезпечності, а винній особі - властивість суспільної небезпечності, у зв'язку з чим винний притягується до передбаченої законом відповідальності [1, с. 107].

А.П. Закалюк зазначає, що особистість злочинця - це сукупність соціально-типових ознак, які сформувалися в процесі неблагополучного соціального розвитку особи, відрізняються своєю суспільною неприйнятністю та крайньою формою останньої - суспільною небезпечністю, зумовлюють криміногенну мотивацію та кримінальну активність особи, безпосередньо спричиняють вчинення злочину [2, с. 239].

Зарубіжні кримінологи припускають, що особа злочинця інтегрує в собі антисуспільні погляди, неприйнятне ставлення до моральних цінностей і обирає суспільно небезпечний шлях поведінки для задоволення своїх потреб [3, с. 12].

Представники Харківської школи кримінології зазначають, що особа злочинця - це складне інтегруюче поняття, яке включає в себе біологічні, психологічні, соціальні сторони людини [4, с. 34]. Вона $€$ певним типом людської особистості, яку формують норми і цінності, що існують у соціумі, та складається з низки ознак, властивостей, рис, особливостей [4, с. 37].

(C) О. М. Бурда, 2020 
3 цього приводу А.П. Закалюк зауважує, що людина не набуває свою особистість від народження, вона випрацьовується в процесі соціального формування особи. Людина не народжується з особистісними рисами злочинця. Вони є продуктом її суспільного неблагополуччя, «випрацювання» [5].

Б.М. Головкін констатує, що особи, які вчинили загальнокримінальні злочини, мають приблизно схожий набір індивідуальних соціально-психологічних ознак. Автор встановив існування статистичної різниці у структурі корисливих рис між корисливими (ненасильницькими) і корисливими насильницькими типами злочинців. Це, за словами вченого, може свідчити про наявність аналогічних відмінних ознак між злочинцями та не злочинцями. Ймовірно, що останні полягають у переважанні за питомою вагою індивідуально-психологічних ознак криміногенного характеру над соціально-позитивними ознаками та утворенні із них якісно неповторної конфігурації міжелементних зв'язків в єдиній системі, якою є особистість злочинця [6, с. 229].

Тому дослідження особи злочинця слід здійснювати, опираючись на сукупність типових соціальних рис і властивостей, які є домінантними у виборі протиправного варіанту поведінки. Важливо в такому разі встановити спрямованість особистості злочинця. На переконання Б.М. Головкіна, спрямованість особистості злочинця - це суб'єктивне сприйняття і ставлення до індивідуально значущих об'єктів, що зумовлює вибір шляхів і засобів досягнення поточних цілей, реалізації життєвих планів [7, с. 184-186].

Для повноцінної кримінологічної характеристики особи злочинця необхідно проаналізувати їі структуру. Кримінологічна структура особистості будується за сукупністю ознак. Найчастіше виокремлюють такі складники кримінологічної структури: соціально-демографічні ознаки (стать, вік, рівень освіти, сімейний стан, рід занять), кримінально-правові ознаки (спрямованість злочинної поведінки, мотив і мета, одноособовий чи груповий характер злочинної діяльності, наявність чи відсутність судимості, вид і розмір призначеного покарання) та морально-психологічні ознаки (потреби, інтереси, світогляд, рівень духовного розвитку, мотиваційна сфера) [8, с. 87-93]. Кримінологічний аналіз структури особи злочинця є досить об'ємним, тому в цій статті безпосередньо розгляну соціально-демографічні ознаки.

Вивчення комплексу соціально-демографічних ознак магазинних крадіїв на підставі вибіркового узагальнення матеріалів кримінальних проваджень показало таку інформацію. Так, за статтю крадіжки з об’єктів роздрібної торгівлі здійснюють здебільшого чоловіки - 77,2\% . Однак приблизно кожна п'ята крадіжка вчиняється жінками - 22,8\%. Прикметно, що частка жінок серед осіб, які вчинили загальнокримінальні злочини, становить $10-11 \%$.

Злочинний умисел чоловіків насамперед спрямований на заволодіння ікрою (червоною та чорною), алкогольними напоями (віскі, коньяк, горілка, міцні вина та вермути), тютюновими виробами (здебільшого дорогі бренди типу “Parliament", “Sobranie”), електронною технікою (мобільні телефони, захисне скло для гаджетів, чохли тощо) та товарами для дому (лампочки, викрутки, щипці, свердла). Жінкки серед предметів злочинних посягань частіше віддають перевагу ковбасним виро- 
бам, замороженому м'ясу, дорогим сортам сирів, парфумам, одягу, який можна швидко і непомітно одягнути поверх свого тощо.

За ознакою віку розподіл засуджених виглядає так: $16-18$ років - 5\% , 19-29 років - 37,8\%, 30-39 років - 32\% , 40-49 років - 12,4\%, 50-59 років - $10 \%, 60$ років і старші - 2,8\% . Більшість $(69,8 \%$ ) крадіїв складають працездатні особи віком від 19 до 39 років. Частка неповнолітніх злочинців із загальної кількості засуджених склала $5 \%$. Кількість осіб похилого віку у загальній структурі злочинності в мережі роздрібної торгівлі є незначною - 2,8\% .

Досить невелика частка неповнолітніх злочинців пояснюється тим, що кримінальна відповідальність за цей вид правопорушень настає з 16 років. Часто через вартість викраденого крадіжки неповнолітніх не можна кваліфікувати як адміністративне правопорушення. Тому більшість злочинів залишаються поза межами статистичного обліку. За дослідженням Б.М. Головкіна неповнолітні хибно сприймають і спотворено трактують задекларовані ринкові цінності. В несформованій дитячій психіці матеріальний добробут постає єдиним критерієм життєвого успіху. Причому формується чітка орієнтація на якомога легший і якнайшвидший шлях досягнення матеріального достатку - привласнити чуже, відібрати, вкрасти, одурити тощо [9, с. 87].

Так, протягом 2017 року у Львові група підлітків неодноразово здійснювала крадіжки із супермаркетів. Вони викрадали лише дорогі товари: елітний алкоголь, мідії, креветки, ікру, шоколад, косметику. Викрадені товари підлітки ховали у спеціально приготовлені сумки. Група налічувала 12 учасників, з них 8 дівчат і 4 хлопців віком від 11 до 17 років. Троє членів групи зізналися у причетності й до інших випадків крадіжок із супермаркетів Львова [10].

Освітній рівень засуджених осіб посередній. Зокрема. із середньою або неповною середньою освітою було засуджено 56,8 \% крадіїв. Середньо-спеціальну освіту мали $16,4 \%$ засуджених. Із професійно-технічною освітою зафіксовано $6 \%$ злочинців. Близько 4,8\% мали неповну вищу освіту. Із повною вищою освітою налічується $14 \%$ засуджених. В розрізі отриманих показників вирізняється досить висока частка засуджених із вищою освітою. Попри це такі особи здебільшого не мають офіційної роботи, що викликає питання щодо їхньої трудової зайнятості. Відповідь на це питання спробую знайти в дослідженні відповідних показників.

За результатами вибіркового узагальнення матеріалів кримінальних проваджень частка працюючих осіб склала $11,2 \%$, а частка непрацюючих $-88.8 \%$ (!). При цьому більшість $(80 \%)$ засуджених за крадіжки із мереж роздрібної торгівлі на момент вчинення злочину склали працездатні особи, але не працюючі, які не мали легальних джерел доходів. Студенти вищих навчальних закладів становлять 4,8\% від загальної кількості засуджених. Пенсіонери серед контингенту засуджених становлять 2,8\%. Учні навчальних закладів складають найменший відсоток від загальної кількості засуджених - 1,2\% .

Встановлені показники вказують на існуючі проблеми трудової зайнятості українського населення, а особливо тієї частини, яка має тільки базову середню освіту. Можливо, через відсутність вищої освіти, безробіття, нужду такі особи змушені йти на злочини, в окремих випадках для забезпечення власного виживання. 
3 іншого боку майже 40\% злочинців, як встановлено показниками освітнього рівня, це особи, які отримали професію та здатні працювати для задоволення елементарних побутових потреб (у їжі, одязі тощо), але в силу тих чи інших обставин змушені вибирати протиправний варіант поведінки.

За родом занять із числа працюючих можна виокремити різноробочих $-39,3 \%$, водіїв - 17,8\%, менеджерів і страхових агентів - 14,3\%, кухарів - 10,7\%, охоронців $-10,7 \%$, лікарів - 3,6\% , директорів і заступників директорів приватних фірм $3,5 \%$ та інших. За родом занять переважають особи, які працюють на непостійних, тимчасових або сезонних роботах, отримують тимчасові заробітки, інколи живуть без легального джерела доходів. Водії, кухарі, охоронці здебільшого є працівниками тих об’єктів роздрібної торгівлі, де здійснюють крадіжки. Це може свідчити про проблему низького рівня оплати праці малокваліфікованих робітників. 3 усієї сукупності професій вирізняються лікарі, особи, які займають посади директора, заступника директора, менеджера, страхового агента. Випадки крадіжок такими особами найчастіше зумовлені пануючою у суспільстві психологією споживацтва.

Дослідження сімейного стану контингенту засуджених засвідчило, що більшість із них становлять неодружені / незаміжні або розлучені особи $(80 \%)$. Частка осіб, які перебувають у шлюбі, склала $20 \%$. Із наведених показників випливає, що в більшості засуджених не було обов'язку утримувати сім'ю, мати додаткові джерела доходів і накопичувати достатню кількість коштів для забезпечення сімейного достатку. Такі особи обирають для задоволення базових потреб найпростіший варіант поведінки - вчиняють крадіжки. Одні викрадають для власного виживання, інші - з метою перепродажу та отримання незначного прибутку. Засуджені ж, які мали сім'ї, вчиняли крадіжки насамперед для забезпечення потреб власної родини. За словами Ю.М. Антоняна та В.Є. Емінова такі злочинці можуть бути досить скромними і з викраденого не брати особисто для себе нічого або ж брати дуже мало [11, с. 162].

Висновки. Так, узагальнення соціально-демографічних ознак контингенту засуджених дозволило встановити, що крадіжки з об’єктів роздрібної торгівлі здійснюють різні за соціальним статусом особи (робітники, обслуговуючий персонал, «інтелігенція», керівники, менеджери, особи без певного роду занять). Здебільшого це особи, які мають лише базову освіту, є працездатними, офіційно не працюють, не мають легальних джерел доходів, не зв'язані сімейними відносинами та обов'язками. 


\section{Jimepamypa}

1. Даньшин И.Н. Общетеоретические проблемы криминологии : монография / И.Н. Даньшин. Харьков : Прапор, 2005. 224 с.

2. Закалюк А.П. Курс сучасної української кримінології. Теорія і практика: у 3 кн. / А.П. Закалюк. К. : Ін Юре, 2007. Кн. 1: Теоретичні засади та історія української кримінологічної науки. 424 с.

3. Ю.М. Антонян, В.Е. Эминов. Личность преступника. Криминолого-психологическое исследование : Монография. М. : Норма: НИЦ ИНФРА-М, 2018. 368 с.

4. Кримінологія: Загальна та Особлива частини : підручник / І.М. Даньшин, В.В. Голіна, М.Ю. Валуйська та ін.; за заг. ред. В.В. Голіни. 2-ге вид. перероб. і доп. Х. : Право, 2009. 288 с.

5. Закалюк А.П. Там само.

6. Головкін Б.М., Наваляна Я.Т. Психологічні особливості злочинців. Форум права. Харків. 2012. Вип. № 4. С. 223-230.

7. Головкін Б.М. Корислива насильницька злочинність в Україні: феномен, детермінація, запобігання : монографія. Харків : Право, 2011. 432 с.

8. Кримінологія : підручник / [Голіна В.В. та ін.]; за ред. проф. В.В. Голіни, Б.М. Головкіна; Нац. юрид. ун-т ім. Ярослава Мудрого. Харків : Право, 2014. 439 с.

9. Б.М. Головкін. Крадіжка як найтиповіший злочин неповнолітніх [Електронний ресурс] / Режим доступу: http://dspace.nlu.edu.ua/bitstream/123456789/10935/1/Golovkin 82-88.pdf.

10. Елітний алкоголь та делікатеси. У Львові спіймали велику банду підлітків за крадіжки з магазинів [Електронний ресурс] / Режим доступу: https://tsn.ua/ukrayina/elitniy-alkogol-ta-delikatesi-ulvovi-spiymali-veliku-bandu-pidlitkiv-za-kradizhki-z-magaziniv-983178.html.

11. Ю.М. Антонян, В.Е. Эминов. Там само. С. 162.

\section{Анотація}

Бурда О. М. Соціально-демографічна характеристика магазинного крадія. - Стаття.

У статті здійснено спробу встановити та проаналізувати питання соціально-демографічної характеристики магазинного крадія. Насамперед до уваги бралися визначення понять «особа злочинця» та «особистість злочинця», значення яких по-різному трактуеться авторами. Незважаючи на відмінності, як вітчизняні, так і зарубіжні кримінологи все ж мають спільну систему ознак особи злочинця.

Для дослідження особи злочинця необхідно опиратися на соціальні риси та властивості, які є домінантними у виборі протиправної (антисуспільної) поведінки особи. До уваги бралися такі ознаки як стать, вік, рівень освіти, сімейний стан, рід занять. Наведені у статті цифрові показники були досліджені та проаналізовані на підставі вибіркового узагальнення матеріалів кримінальних проваджень. Було встановлено, що третя частина крадіжок, які вчиняються в мережі роздрібної торгівлі, здійснюється чоловіками. Їх увагу привертають дороговартісні товари (такі як ікра, алкоголь тощо). Тоді як жінками здійснюються крадіжки товарів життєвої необхідності (продукти харчування, засоби гігієни). Абсолютну більшість засуджених за крадіжки з мереж роздрібної торгівлі на момент вчинення злочину склали працездатні не працюючі особи.

Окремої уваги потребують неповнолітні злочинці. Як відомо, кримінальна відповідальність настає з 16-річного віку, тому досить часто через недостатню вартість викраденого товару крадіжки неповнолітніх не можна кваліфікувати як адміністративне порушення. Тому більшість злочинів перебувають поза межею статистичного обліку.

Щодо освітнього рівня, то майже половина злочинців має базову середню освіту, тобто є працездатною, але в силу тих чи інших обставин вони вимушені вибирати кримінальний шлях. Більшість серед працездатних осіб за родом занять виявилися різноробочими. Здебільшого це особи, які працюють на тимчасовій, непостійній роботі. Деякі професії пов'язані безпосередньо з місцем вчинення крадіжок. Крім того, слід звернути увагу на те, що майже всі крадії були неодружені (незаміжні), тому в них не було обов'язку утримувати сім'ю.

Ключові слова: мережа роздрібної торгівлі, рітейл, шопліфтер, крадіжки, супермаркет, магазин. 


\section{Summary}

Burda O. M. Socio-demographic characteristics of shoplifting. - Article.

The article attempts to establish and analyze the socio-demographic characteristics of shoplifting. First of all, the definitions of "criminal person" and "criminal personality" were taken into account, their understanding is interpreted differently by the authors. But despite the difference, both domestic and foreign criminologists still have a common system of personality traits of the offender. To study the identity of the offender, it is necessary to rely on social traits and characteristics that are dominant in the choice of illegal (anti-social) behavior of the person. Such components as gender, age, level of education, marital status, occupation were taken into account.

Based on the digital indicators presented in the article, they were researched and analyzed on the basis of selective generalization of materials of criminal proceedings. It was found that a third of thefts committed in the retail network are committed by men. They account for expensive goods (such as caviar, alcohol, etc.). While women steal essential goods (food, hygiene products).

The vast majority of those convicted of theft from retail chains, at the time of the crime, were able-bodied, but not working. Juvenile delinquents need special attention. As you know, criminal liability begins at the age of 16 , so often due to the insufficient cost of stolen goods, theft of minors can not be classified as an administrative offense.

As a result, most crimes are outside the realm of statistics. As for the educational level, almost half of criminals have a basic secondary education, ie able-bodied, but due to certain circumstances, they are forced to choose a criminal path. Among the able-bodied occupations, persons turned out to be handymen, mostly persons working in temporary, non-permanent jobs. And some professions are directly related to the place of theft. In addition, it should be noted that almost all thefts were unmarried, as a result, they had no obligation to support the family.

Key words: retail chain, retail, shoplifter, theft, supermarket, shop. 